\title{
Algengi kynferðislegrar áreitni og ofbeldis gegn íslenskum unglingum
}

\author{
Ársæll Már Arnarsson ${ }^{1}$ faraldsfræðingur, Kristín Heba Gísladóttir¹ sérfræðingur i félagsvísindum, Stefán Hrafn Jónsson² félagsfræðingur
}

\section{ÁGRIP}

Inngangur: Kynferðisleg áreitni og ofbeldi gagnvart börnum og unglingum er ein alvarlegasta ógn við heilbrigði peirra. Markmiðið var að rannsaka algengi og áhrif pess á íslenska unglinga í 10. bekk.

Efniviður og aðferðir: Rannsóknin byggir á gögnum úr íslenska hluta HBSC-rannsóknarinnar á heilsu og lífskjörum skólabarna. Alls tóku 3618 íslenskir nemendur pátt í alpjóðlegri spurningalistarannsókn sem lögð var fyrir alla nemendur í 10. bekk í ölum skólum landsins að einum undanskildum. Reynsla nemenda af kynferðislegri áreitni og ofbeldi var metin með pví að spyrja hversu oft pau hefðu gegn sínum vilja verið: a) snert með kynferðislegum hætti, b) verið látin snerta annan einstakling með kynferðislegum hætti, c) verið reynt að hafa við pau samfarir eða munnmök eða d) einhverjum hefði tekist að hafa við pau samfarir eða munnmök.
Niðurstöður: Niðurstöður leiddu í ljós að 14,6\% (527) pátttakenda höfðu orðið fyrir einhvers konar kynferðislegri áreitni eða ofbeldi. Af peim höfðu $4,5 \%$ (162) orðið fyrir slíku einu sinni en 10,1\% (365) höfðu annaðhvort orðið oftar fyrir ákveðinni gerð ofbeldis eða pví hafði verið beitt gegn peim á margvíslegri hátt. Um $1 \%$ pátttakenda, eða 35 einstaklingar, sögðust hafa orðið mjög oft fyrir nær öllum gerðum ofbeldis og áreitni. Tínni vanlíðunar og áhættuhegðunar var mun hærri hjá peim sem höfðu orðið fyrir kynferðislegri áreitni eða ofbeldi.

Ályktun: Pó niðurstöðurnar sýni að algengi kynferðislegrar áreitni og ofbeldis gegn unglingum sé svipað og í öđrum vestrænum löndum er pað nokkuð hærra en sambærileg rannsókn á Íslandi leiddi i ljós fyrir áratug.
Fyrirspurnir: Ársæll Már Arnarsson aarnarsson@unak.is

Greinin barst 22. október 2015, sampykkt til birtingar 3. maí 2016.

\section{Inngangur}

Kynferðislegt ofbeldi og áreitni gagnvart börnum og unglingum er ein mesta ógn við heilbrigði peirra vegna pess hversu alvarlegar afleiðingar pað getur haft í för með sér. Рað er pví ekki að undra að umræðan um petta vandamál hafi verið mikil undanfarna áratugi. Samhliða hafa birst fjölmargar rannsóknir á pessu sviði, svo sem á afleiðingum, orsökum og við hvaða aðstæður slíkt ofbeldi á sér stað, ${ }^{1}$ en ekki síður hversu algengt pað er. ${ }^{2,3}$ Í ljós hefur komið að slíkt ofbeldi eykur sálræn vandamál og áhættuhegðun hvort sem pað felur í sér líkamlega snertingu eður ei. ${ }^{4}$ Algengt er einnig að afleiðingarnar séu viðvarandi fram á fullorðinsár. ${ }^{5}$

Kynferðislegt ofbeldi felur í sér kynferðislega hegðun gagnvart einstaklingi sem er höfð í frammi gegn vilja, án sampykkis, með ofbeldi, stjórnun eða ógnandi hætti. ${ }^{6}$ Kynferðislegt ofbeldi gagnvart barni telst samkvæmt Alpjóðaheilbrigðisstofnuninni (World Health Organization - WHO) vera öll pátttaka barns í hverskyns kynferðislegum athöfnum sem pað skilur ekki til fullnustu, er ófært um að veita sampykki fyrir, hefur ekki proska til að veita sampykki, brýtur gegn landslögum eða samfélagslegum viðmiðum. Slíkt ofbeldi gagnvart barni getur átt sér stað milli tveggja barna eða milli barns og fullorðins einstaklings sem hefur yfirburðastöðu gagnvart polandanum, til að mynda með tilliti til aldurs, proska, stöðu eða líkamlegra yfirburða. ${ }^{7}$

Talið er að ein af hverjum premur til fjórum konum og einn af hverjum 6 til 10 körlum hafi orðið fyrir kynferðislegu ofbeldi í æsku. Stúlkur eru prisvar sinnum líklegri en drengir til að verða fyrir slíku. Meirihluti peirra barna sem verður fyrir kynferðislegu ofbeldi í æsku pekkir brotamanninn (49-84\%) og í 12-20\% tilfella á ofbeldið sér stað innan fjölskyldu brotapola. ${ }^{7}$

Íslensk rannsókn meðal 16-19 ára ungmenna sýndi fram á að 36\% stúlkna og 18\% drengja höfðu orðið fyrir kynferðislegu ofbeldi. ${ }^{8}$ Pær niðurstöður voru svipaðar peim sem komu fram í safngreiningu (meta-analysis) rannsókna frá Norður-Ameríku, en samkvæmt henni höfðu um 30\% stúlkna og 15\% drengja upplifað slíkt. ${ }^{9}$ Hærri tíðni kom fram í sænskri rannsókn á ungmennum á framhaldsskólaaldri en niðurstöður peirrar könnunar leiddi í ljós að 65\% stúlkna og 23\% drengja höfðu orðið fyrir kynferðislegu ofbeldi. ${ }^{10}$

Mjög mikill munur er pó á algengi kynferðislegs ofbeldis gagnvart börnum og unglingum eftir rannsóknum par sem niðurstöðurnar spanna allt frá $2 \%$ upp í 65\%. ${ }^{9}$ Á pessum mikla breytileika eru ýmsar mögulegar skýringar. Helst ber að nefna að ekki eru allir rannsakendur sammála um hvernig skilgreina beri slíkt ofbeldi, við hvaða aldur skuli miða, hvort ákveðinn aldursmunur purfi að vera milli polanda og geranda, hvort nauðung purfi að koma til og hvers eðlis verknaðurinn er til að teljast kynferðislegt ofbeldi..,11 pegar kynferðislegt ofbeldi er skilgreint með víðustum hætti er öll kynferðisleg hegðun gagnvart barni talin til kynferðislegs ofbeldis og parf pá snerting ekki að koma til. En í öðrum rannsóknum hefur kynferðislegt ofbeldi verið skilgreint pannig að snerting purfi að eiga sér stað. Pegar allra prengsta skilgreiningin er notuð 
er gert ráð fyrir pví að ekki aðeins snerting heldur samræði purfi að eiga sér stað. ${ }^{11}$ Í rannsóknum par sem skilgreining á kynferðislegu ofbeldi felur einungis í sér sifjaspell eða samræði er algengið vitanlega metið mun lægra. ${ }^{2}$ Úrtaksaðferð er einnig mismunandi í pessum rannsóknum sem gerir beinan samanburð erfiðari. ${ }^{12}$ Langflestar rannsóknir benda til að stúlkur séu frekar polendur en drengir. ${ }^{2}$

Rannsóknir hafa sýnt að kynferðislegt ofbeldi hefur ýmiskonar sálræn áhrif og eykur sjálfsvígshugsanir meðal unglinga, jafnvel óháð pví hvort pau sýna jafnframt einkenni punglyndis.. ${ }^{13,14}$ Einnig eru tengsl við vímuefnanotkun ${ }^{15}$ og ýmiskonar geðraskanir ${ }^{16,17}$ eins og punglyndi, ${ }^{18,19} \mathrm{kvíða}^{19}$ og áfallastreituröskun ${ }^{20,21}$ vel pekkt. Rannsóknir á íslenskum unglingum hafa sýnt tengsl kynferðisofbeldis við bæði reiði og depurð. ${ }^{8}$

Markmið rannsóknarinnar var að meta hversu algengt er að unglingar í 10. bekk á Íslandi hafi orðið fyrir kynferðislegri áreitni eða ofbeldi og hvort slík reynsla tengist áhættuhegðun og vanlíðan.

\section{Efniviður og aðferðir}

Pessi rannsókn er byggð á gögnum sem safnað var í íslenskum hluta HBSC-rannsóknarinnar á heilsu og lífskjörum skólabarna (Health and behaviour of school-aged children). Gagnasöfnun rannsóknarinnar fer fram á fjögurra ára fresti í rúmlega 40 Evrópulöndum og er studd af Alpjóðaheilbrigðisstofnuninni (WHO). ${ }^{22}$

Íslensk pýðing á alpjóðlegum spurningalista var lögð fyrir alla nemendur í 6., 8. og 10. bekk í öllum skólum landsins sem mættir voru í skólann á fyrirlagnardaginn, í febrúar 2014. Einn skóli, Sæmundarskóli í Reykjavík, hafnaði pátttöku. Annars tóku allir skólar pátt. Spurningar um kynferðislega áreitni og ofbeldi voru einungis lagðar fyrir nemendur í 10. bekk, en af peim tóku 3618 pátt, eða sem samsvarar 85\% allra nemenda sem skráðir voru í 10. bekk. Kynjaskipting var nánast jöfn - 1783 (50,7\%) voru karlkyns og 1731 (49,3\%) kvenkyns en 104 nemendur svöruðu ekki spurningunni um kyn.

Til pess að afla upplýsinga um hvort nemendur hefðu orðið fyrir kynferðislegu ofbeldi eða áreitni voru peir spurðir hvort peir hefðu gegn vilja sínum: a) verið snertir með kynferðislegum hætti, b) verið látnir snerta annan einstakling með kynferðislegum hætti, c) orðið fyrir tilraun til samfara eða munnmaka eða d) orðið fyrir pví að einhverjum hefði tekist að hafa við pá samfarir eða munnmök. Svarmöguleikarnir voru: „Ég neita að svara“, „Aldrei“, „Einu sinni“, „Nokkrum sinnum" og "Oft". Pessar spurningar byggjast á styttri og staðlaðri útgáfu af "Adverse Childhood Experiences questionnaire $^{423}$ og eru hluti af hinum alpjóðlega HBSC-spurningalista. 22

Einnig voru notaðar spurningar um daglegar reykingar, reynslu af kannabis og hvort unglingarnir hefðu orðið drukknir oftar en 10 sinnum um ævina. Pessar spurningar hafa verið notaðar í HBSC-rannsókninni frá árinu 1985 og hafa verið sérstaklega skoðaðar með tilliti til réttmætis og áreiðanleika sem hvorttveggja hefur reynst fullnægjandi. ${ }^{23}$

Unglingarnir voru einnig spurðir um hversu oft peir upplifðu höfuðverki, magaverki, bakverki, depurð, pirring eða vont skap, væru taugaóstyrkir eða ættu við svefnörðugleika að stríða.
Svarmöguleikar voru nokkrir en í pessari rannsókn var hópnum skipt í tvennt; pá sem sögðust upplifa slíkt nær daglega og hina sem gerðu pað sjaldnar. Pessar spurningar eru hluti af „HBSC Symptoms Checklist“ sem var fyrst lagður fyrir í alpjóðlegu rannsókninni árið 1993 og hefur sýnt sig hafa bæði ágætis réttmæti og endurprófunaráreiðanleika $(\mathrm{r}=0,79) \cdot{ }^{24}$

Pá var einnig spurt um reynslu svarenda af einelti - bæði pví hvort peir hefðu verið lagðir í einelti og hvort peir hefðu lagt aðra í einelti. Pessar spurningar eru teknar upp úr spurningalista Olweus ${ }^{25}$ og hafa verið hluti af HBSC-rannsókninni frá árinu 2001. Réttmæti og áreiðanleiki peirra hefur verið staðfestur og pær hafa verið notaðar í fjölda annarra rannsókna. ${ }^{22}$ Í pessari grein var litið sérstaklega til peirra sem svöruðu að peir upplifðu slíkt oft í hverri viku.

Að lokum var spurt um líðan nemendanna í skóla og peir sem sögðu að sér liði alls ekki vel voru teknir sérstaklega til skoðunar. Pessi spurning hefur verið hluti af HBSC-listanum frá árinu 1985 en hefur enn ekki verið rannsökuð með tilliti til réttmætis. ${ }^{22}$

Rannsóknin byggir á ópersónugreinanlegum gögnum og pví ekki leyfisskyld en var tilkynnt til Persónuverndar (tilkynning númer S6463). Eftir að kynningarbréf og eintak af spurningalistanum hafði verið sent til skólastjóra allra grunnskóla á Íslandi var haft samband við pá og peir beðnir um leyfi til að leggja fyrir spurningalistann. Allir gáfu leyfi sitt að undanskildum Sæmundarskóla í Reykjavík. Öllum forráðamönnum var síðan sent upplýsingabréf par sem peim var kynnt efni rannsóknarinnar og peim gefinn kostur á að hafna pátttöku. Að auki var öllum pátttakendum gerð grein fyrir pví á forsíðu spurningalistans að pau pyrftu hvorki að taka pátt né heldur að svara öllum spurningunum.

Nemendur svöruðu útprentuðum spurningalista skriflega í kennslustund og skiluðu honum ómerktum í lokuðu umslagi. Kennari eða starfsmaður rannsóknarinnar sáu um að safna umslögunum saman.

Par sem ekki var um að ræða rannsókn á úrtaki heldur á nær öllu pýðinu var ekki notast við ályktunartölfræði við úrvinnslu gagna.

\section{Niðurstöður}

Alls sögðust 14,6\% (527) pátttakenda hafa orðið fyrir kynferðislegri áreitni eða ofbeldi. Af peim sögðust 4,5\% (162) hafa orðið fyrir slíku einu sinni, en 10,1\% (365) höfðu annaðhvort orðið oftar fyrir ákveðinni gerð áreitni eða ofbeldis eða pví hafði verið beitt gegn peim á margvíslegan hátt. Langalgengast var að peir sem hefðu orðið einu sinni fyrir slíku hefðu verið snertir með kynferðislegum hætti. Um 1\% pátttakenda bæði pilta og stúlkna, eða alls 35 einstaklingar, sögðust hafa orðið mjög oft fyrir nær öllum gerðum ofbeldis og áreitni.

Í töflu I sést hversu algengt pað var að pátttakendur hefðu orðið fyrir kynferðislegri áreitni eða ofbeldi, flokkað eftir kyni. Alls slepptu 158 strákar að svara spurningunni „Hefur einhver snert pig eða káfað á pér með kynferðislegum hætti gegn pínum vilja?“ og 64 að auki neituðu að svara. Af peim 1561 strákum sem tóku afstöðu sögðust 6,5\% einhvern tíma hafa orðið fyrir slíku. Mun fleiri stelpur tóku ekki afstöðu til spurningarinnar, eða 406, en svipað 
Tafla I. Algengi kynferðislegrar áreitni og ofbeldis gegn unglingum í 10. bekk, n (\%).

\begin{tabular}{|c|c|c|}
\hline & Strákar & Stelpur \\
\hline \multicolumn{3}{|c|}{$\begin{array}{l}\text { Hefur einhver snert pig eða káfað á pér með } \\
\text { kynferðislegum hætti gegn pínum vilja? }\end{array}$} \\
\hline Neita að svara & $64(3,9)$ & $67(4,2)$ \\
\hline Aldrei & $1460(89,8)$ & $1258(78,9)$ \\
\hline Einu sinni & $39(2,4)$ & $150(9,4)$ \\
\hline Nokkrum sinnum & $31(1,9)$ & $86(5,4)$ \\
\hline Oft & $31(1,9)$ & $33(2,1)$ \\
\hline \multicolumn{3}{|c|}{$\begin{array}{l}\text { Hefur einhver annar látið pig snerta sig með } \\
\text { kynferðislegum hætti gegn pínum vilja? }\end{array}$} \\
\hline Neita að svara & $59(3,6)$ & $41(2,6)$ \\
\hline Aldrei & $1501(92,4)$ & $1423(89,2)$ \\
\hline Einu sinni & $30(1,8)$ & $84(5,3)$ \\
\hline Nokkrum sinnum & $19(1,2)$ & $31(1,9)$ \\
\hline Oft & $15(0,9)$ & $17(1,1)$ \\
\hline \multicolumn{3}{|c|}{ Hefur einhver reynt að hafa við pig samfarir eða munnmök gegn pínum vilja } \\
\hline Neita að svara & $49(3,0)$ & $52(3,3)$ \\
\hline Aldrei & $1474(90,9)$ & $1345(84,5)$ \\
\hline Einu sinni & $43(2,7)$ & $114(7,2)$ \\
\hline Nokkrum sinnum & $32(2,0)$ & $60(3,8)$ \\
\hline Oft & $24(1,5)$ & $21(1,3)$ \\
\hline \multicolumn{3}{|c|}{$\begin{array}{l}\text { Hefur einhverjum tekist að hafa við pig samfarir } \\
\text { eða munnmök gegn pínum vilja? }\end{array}$} \\
\hline Neita að svara & $54(3,3)$ & $50(3,1)$ \\
\hline Aldrei & $1504(92,7)$ & $1437(90,3)$ \\
\hline Einu sinni & $24(1,5)$ & $63(4,0)$ \\
\hline Nokkrum sinnum & $21(1,3)$ & $22(1,4)$ \\
\hline Oft & $19(1,2)$ & $19(1,2)$ \\
\hline
\end{tabular}

margar stúlkur og drengir neituðu að svara, eða 67. Af peim 1527 stúlkum sem tóku afstöðu kváðust 17,6\% einhvern tíma hafa orðið fyrir snertingu eða káfi gegn eigin vilja. Stúlkur voru um pað bil fjórum sinnum líklegri en strákar til pess að hafa orðið fyrir snertingu eða káfi einu sinni eða nokkrum sinnum, en munurinn milli kynjanna var nær enginn meðal peirra sem sögðust oft hafa lent í slíku.

Til spurningarinnar „Hefur einhver annar látið pig snerta sig með kynferðislegum hætti gegn pínum vilja?“ tóku 1565 strákar og 1555 stelpur afstöðu, en 159 strákar svöruðu engu og 59 neituðu að svara. Sambærilegar tölur fyrir stelpur voru 135 og 41. Af peim sem svöruðu sögðust 4,1\% stráka en 8,5\% stelpna hafa orðið fyrir slíku. Stúlkur voru um pað bil prisvar sinnum líklegri en strákar til að hafa upplifað slíkt einu sinni en munurinn milli kynjanna var minni meðal peirra unglinga sem höfðu oftar lent í pessháttar aðstæðum.

Af peim sem tóku afstöðu til spurningarinnar „Hefur einhver reynt að hafa við pig samfarir eða munnmök gegn pínum vilja?“ sögðust 6,3\% stráka og 12,7\% stelpna hafa orðið fyrir slíku. Alls slepptu 161 strákur og 139 stelpa að svara og að auki neituðu 49 strákar og 52 stelpur að svara. Stúlkurnar voru mun líklegri en strákarnir til að greina frá slíkri reynslu nema meðal peirra sem höfðu oftast orðið fyrir slíku en par var nær enginn munur á kynjunum.

Pegar pátttakendur voru inntir eftir pví hvort einhverjum hefði tekist að hafa við pá samfarir eða munnmök gegn vilja peirra, slepptu 301 peirra að svara (161 strákar og 140 stelpur) og auk pess neituðu 104 að svara (54 strákar og 50 stelpur). Af peim sem tóku afstöðu reyndust 4,1\% stráka og 6,7\% stúlkna vera polendur pessháttar ofbeldis. Stúlkur voru mun líklegri en strákar til pess að hafa einu sinni orðið fyrir slíku en meðal peirra sem höfðu oftar orðið fyrir slíku ofbeldi var enginn munur á kynjunum.

Í töflu IIa sjást tengsl ýmissa neikvæðra mælinga við reynslu unglinganna af pví að hafa orðið fyrir kynferðislegu káfi gegn eigin vilja. Í öllum mælingum nema einni (lögð/lagður í einelti oft í viku) sést að útkoman fyrir pá sem hafa einu sinni lent í slíku er um pað bil tvöfalt líklegri til að vera neikvæð en fyrir pá sem aldrei hafa lent í pvílíku. Hópurinn sem oft hefur orðið fyrir kynferðislegu káfi gegn sínum vilja sker sig hins vegar úr með mjög afgerandi hætti og ljóst að tengingin við ýmiskonar áhættuhegðun og vanlíðan er afar sterk meðal peirra. Einnig er athyglisvert að sjá að peir unglingar sem merktu sérstaklega við að peir neituðu að svara hafa talsvert neikvæðari útkomu en peir sem aldrei sögðust hafa orðið fyrir slíku.

Daglegar reykingar voru mun algengari meðal peirra unglinga sem höfðu orðið fyrir kynferðislegu káfi en pær virtust aukast enn meira meðal stúlkna. Pannig sögðust 0,7\% stúlkna sem aldrei hafði verið káfað á kynferðislega reykja daglega, en 34,4\% peirra sem oft höfðu orðið fyrir slíku. Рað sama átti við um 1,6\% og 19,4\% strákanna. Að hafa orðið fyrir kynferðislegu káfi jók einnig líkurnar á pví að unglingarnir hefðu orðið drukknir 10 sinnum eða oftar og voru áhrifin meiri meðal stúlkna en drengja. Meðal peirra stúlkna sem aldrei höfðu orðið fyrir slíku höfðu 0,6\% orðið drukknar svo oft um ævina en pað sama átti við um $34,4 \%$ peirra sem sögðust oft hafa orðið fyrir kynferðislegu káfi. Sambærilegar tölur fyrir stráka voru 1,2\% og 25,8\%. Ekki sást munur milli kynja í öðrum mælingum á breytum í töflu IIa.

Í töflu IIb eru sýnd tengsl pess að unglingar hafi verið látnir snerta einhvern annan með kynferðislegum hætti gegn sínum vilja, við sömu neikvæðu mælingarnar og í töflu IIa. Í stuttu máli má segja að sama mynstrið komi fram með enn sterkari neikvæðum hætti. Polendur voru líklegri til að hafa verið lagðir í einelti nokkrum sinnum í viku, með enn sterkari hætti hjá strákum en stelpum. Meðal strákanna voru 0,3\% peirra sem aldrei höfðu verið látnir snerta annan með kynferðislegum hætti gegn vilja sínum lagðir í einelti svo oft, en pað sama átti við um 40,0\% peirra sem oft höfðu upplifað slíkt kynferðisofbeldi. Sambærilegar tölur fyrir stúlkurnar voru $0,6 \%$ og 23,5\%. Petta virtist einnig hafa meiri áhrif á líðan stráka í skóla en stúlkna. Af peim strákum sem aldrei höfðu lent í slíku sögðust 2,5\% að sér liði alls ekki vel í skólanum en 40,0\% peirra sem oft höfðu gert pað. Раð sama átti við um 1,7\% og 17,6\% stúlkna. Annar kynjamunur greindist ekki í mælingum sem birtar eru í töflu II.

Í töflu IIc par sem áhrif pess að einhver hafi reynt að hafa við unglingana samfarir eða munnmök gegn peirra vilja eru skoðuð eru tengslin við neikvæða pætti jafn afgerandi og í töflu IIb. Ekki 
var hægt að sjá merkjanlegan mun á áhrifum slíkra tilrauna eftir kyni polenda.

Í töflu IId sést útkoman fyrir pá sem orðið hafa fyrir nauðgun. Eins og vænta mátti voru áhrif ofbeldisins sterkust á pennan hóp og pau voru að minnsta kosti tífalt líklegri til að falla innan neikvæðra mælinga en peir sem aldrei hafa lent í viðlíka. Um helmingur peirra sem hafa orðið fyrir nauðgun höfðu pannig orðið drukkin oftar en 10 sinnum og sama hlutfall hafði prófað kannabis. Munurinn á reynslu pessara unglinga og annarra af mjög tíðu einelti var einnig mjög afdráttarlaus - pau voru líklegri til pess að vera bæði gerendur og polendur eineltis. Enginn munur sást á milli kynja í peim breytum sem skoðaðar voru í töflu IId.

\section{Umræða}

Alls hafa 14,6\% íslenskra unglinga í 10. bekk orðið fyrir einhvers konar kynferðislegu ofbeldi eða áreitni, sem er svipað algengi og í flestum rannsóknum sem styðjast við svipaðar skilgreiningar. Um priðjungur peirra kvaðst hafa upplifað slíkt einu sinni. Athygli vekur að tveir priðju hlutar sögðust hafa ítrekað orðið fyrir kynferðislegu ofbeldi eða áreitni. Mun algengara var að stúlkur hefðu orðið fyrir öllum gerðum ofbeldisins, en kynjahlutfallið var reyndar frekar jafnt í peim hóp sem oftast hafði orðið oft fyrir barðinu á slíku. Um $1 \%$ pátttakenda sagðist mjög oft hafa orðið fyrir kynferðislegu ofbeldi eða áreitni og upplifað allar tegundir slíks.

Pó umfang kynferðislegrar áreitni og ofbeldis gegn unglingum sé álíka mikið hér á landi og annars staðar á Vesturlöndum er vert að taka fram að pað er talsvert hærra nú en í svipaðri íslenskri rannsókn frá árinu $2004,{ }^{26}$ par sem pað mældist 11,5\% fyrir sama aldurshóp. Pessi aukning verður í fljótu bragði ekki skýrð með mismunandi aðferðafræði og hlýtur að kalla á frekari greiningu.

prátt fyrir að pessi rannsókn leiði í ljós að kynferðisleg áreitni og ofbeldi gagnvart unglingum í 10. bekk sé algengt, er mikilvægt að benda á að rannsóknir frá Bandaríkjunum ${ }^{27}$ sýna að mjög fjölgar í hópi polenda á síðari hluta unglingsára, og pá sérstaklega meðal stúlkna. Pannig kom í ljós í umræddri rannsókn að fjöldi stúlkna sem hafði orðið fyrir slíku jókst úr 17\% meðal 15 ára upp í $27 \%$ meðal 17 ára. Samsvarandi tölur fyrir drengi á sama aldri voru $4 \%$ sem jókst upp í 5\%. Petta kann að skýra muninn á niðurstöðum pessarar greinar og og rannsóknar á eldri íslenskum unglingum sem sýndu hærri tíðni. ${ }^{8}$

Niðurstöður pessarar rannsóknar sýna skýr tengsl milli kynferðislegrar áreitni og ofbeldis annars vegar og neikvæðra pátta í lífi unglinganna hins vegar. Margfalt algengara er að peir sem hafa orðið fyrir slíku hafi oft orðið drukknir, reyki tóbak og hafi prófað kannabis. Peir eru einnig mun líklegri til pess að pjást af verkjum, eiga í svefnörðugleikum, vera pirraðir og taugaóstyrkir. Mun fleiri peirra tengjast líka einelti - bæði sem polendur og gerendur. Upplifun peirra af skólastarfi er sömuleiðis mun neikvæðari. •ó að peir unglingar sem oftast hafa orðið fyrir kynferðislegu ofbeldi eða áreitni hafi augljóslega neikvæðustu útkomuna á pessum páttum, er ljóst að jafnvel peir sem aðeins hafa orðið einu sinni fyrir slíku koma mun verr út en hinir sem aldrei hafa upplifað pvíumlíkt.

Pessi tengsl milli kynferðislegrar áreitni og ofbeldis annars vegar og vanlíðunar og áhættuhegðunar hins vegar hafa ítrekað komið fram í fyrri rannsóknum. Safngreiningar hafa sýnt fram á fylgni milli kynferðislegs ofbeldis eða áreitni í æsku og aukinnar hættu á sálrænum einkennum almennt en pó sérstaklega á áfallastreituröskun, punglyndi og sjálfsvígshættu. Pá hefur einnig verið sýnt fram á í fjölmörgum rannsóknum að slík reynsla eykur líkurnar á vímuefnavanda meðal fórnarlamba. Fræðimenn á sviðinu hafa varað við peim vítahring sem pessir einstaklingar geta lent í pegar peir nota vímuefni til að vinna gegn vanlíðan í kjölfar ofbeldisins en verða um leið útsettari fyrir frekari misnotkun. ${ }^{28}$ Í grein eftir Kristman-Valente og félaga ${ }^{29} \mathrm{kom}$ fram að раð hvort ungmenni hefðu reynslu af slíku eða ekki spáði fyrir um pað hvort peir reyktu oft eða ekki. Раð spáði hins vegar ekki fyrir um pað hvort peir hefðu prófað að reykja einhvern tíma um ævina. Petta er í samræmi við okkar niðurstöður.

Tafla II. Tengsl ólikra gerða kynferðislegrar áreitni og ofbeldis við vanlíðan og áhættuhegðun. N (\%).

\begin{tabular}{|c|c|c|c|c|c|}
\hline \multirow[t]{2}{*}{ Ila } & \multicolumn{5}{|c|}{ Hefur einhver snert pig eða káfað á pér með kynferðislegum hætti gegn pínum vilja? } \\
\hline & Aldrei & Einu sinni & Nokkrum sinnum & Oft & Neitar að svara \\
\hline Reykir daglega & $35(1,3)$ & $11(5,8)$ & $8(6,8)$ & $22(31,4)$ & $13(9,3)$ \\
\hline Orðið drukkin/n oftar en 10 sinnum & $26(0,9)$ & $11(5,8)$ & $8(6,7)$ & $22(31,9)$ & $10(7,1)$ \\
\hline Prófað kannabis & $138(5,0)$ & $32(16,8)$ & $18(15,1)$ & $29(42,6)$ & $16(11,3)$ \\
\hline Höfuðverkur nær daglega & $120(4,3)$ & $22(11,5)$ & $21(17,5)$ & $25(36,2)$ & $16(11,2)$ \\
\hline Magaverkur nær daglega & $95(3,4)$ & $14(7,4)$ & $7(5,8)$ & $18(25,7)$ & $10(7,1)$ \\
\hline Bakverkur nær daglega & $238(8,6)$ & $36(18,8)$ & $22(18,3)$ & $20(28,6)$ & $25(17,7)$ \\
\hline Depurð nær daglega & $173(6,3)$ & $45(23,7)$ & $37(31,1)$ & $24(33,8)$ & $28(20,0)$ \\
\hline Pirringur eða vont skap nær daglega & $214(7,8)$ & $40(20,9)$ & $35(29,2)$ & $25(35,7)$ & $20(14,2)$ \\
\hline Taugaóstyrk/ur nær daglega & $188(6,8)$ & $34(18,0)$ & $36(30,0)$ & $25(36,8)$ & $28(20,0)$ \\
\hline Svefnörðugleikar nær allar nætur & $240(8,7)$ & $43(22,5)$ & $29(24,2)$ & $24(34,8)$ & $29(20,6)$ \\
\hline Leggur í einelti oft í viku & $13(0,5)$ & $2(1,1)$ & $3(2,5)$ & $13(18,8)$ & $8(5,8)$ \\
\hline Lögð/lagður í einelti oft í viku & $6(0,2)$ & $0(0,0)$ & $0(0,0)$ & $11(16,2)$ & $3(2,2)$ \\
\hline Líður alls ekki vel í skóla & $54(1,9)$ & $10(5,2)$ & $9(7,5)$ & $114(20,0)$ & $14(9,9)$ \\
\hline
\end{tabular}




\begin{tabular}{|c|c|c|c|c|c|}
\hline \multirow[t]{2}{*}{ llb } & \multicolumn{5}{|c|}{ Hefur einhver annar látið pig snerta sig með kynferðislegum hætti gegn pínum vilja? } \\
\hline & Aldrei & Einu sinni & Nokkrum sinnum & Oft & Neitar að svara \\
\hline Reykir daglega & $40(1,4)$ & $13(11,2)$ & $6(11,8)$ & $16(44,4)$ & $14(12,8)$ \\
\hline Orðið drukkin/n oftar en 10 sinnum & $33(1,1)$ & $8(6,9)$ & $8(16,0)$ & $20(55,6)$ & $9(8,4)$ \\
\hline Prófað kannabis & $166(5,6)$ & $22(19,3)$ & $12(24,0)$ & $23(63,9)$ & $12(11,1)$ \\
\hline Höfuðverkur nær daglega & $143(4,8)$ & $21(18,3)$ & $8(15,7)$ & $19(52,8)$ & $13(11,9)$ \\
\hline Magaverkur nær daglega & $106(3,6)$ & $14(12,1)$ & $3(6,0)$ & $12(33,3)$ & $119(10,2)$ \\
\hline Bakverkur nær daglega & $272(9,2)$ & $29(25,0)$ & $9(17,6)$ & $14(38,9)$ & $17(15,7)$ \\
\hline Depurð nær daglega & $228(7,7)$ & $36(31,3)$ & $12(23,5)$ & $17(47,2)$ & $16(14,8)$ \\
\hline Pirringur eða vont skap nær daglega & $256(8,6)$ & $30(29,3)$ & $13(25,5)$ & $18(50,0)$ & $15(13,9)$ \\
\hline Taugaóstyrk/ur nær daglega & $236(8,0)$ & $30(26,1)$ & $12(23,5)$ & $17(48,6)$ & $17(16,2)$ \\
\hline Svefnörðugleikar nær allar nætur & $280(9,4)$ & $30(25,9)$ & $14(27,5)$ & $19(54,3)$ & $24(22,2)$ \\
\hline Leggur í einelti oft í viku & $14(0,5)$ & $4(3,5)$ & $1(2,0)$ & $12(33,3)$ & $9(8,5)$ \\
\hline Lögð/lagður í einelti oft í viku & $5(0,2)$ & $0(0,0)$ & $1(2,0)$ & $11(30,6)$ & $4(3,8)$ \\
\hline Líður alls ekki vel í skóla & $63(2,1)$ & $8(6,8)$ & $7(13,7)$ & $11(31,4)$ & $12(11,1)$ \\
\hline \multirow[t]{2}{*}{ Ilc } & \multicolumn{5}{|c|}{ Hefur einhver reynt að hafa við pig samfarir eða munnmök gegn pínum vilja? } \\
\hline & Aldrei & Einu sinni & Nokkrum sinnum & Oft & Neitar að svara \\
\hline Reykir daglega & $37(1,3)$ & $8(5,0)$ & $8(8,7)$ & $19(38,8)$ & $16(13,9)$ \\
\hline Orðið drukkin/n oftar en 10 sinnum & $26(0,9)$ & $8(5,0)$ & $10(10,9)$ & $22(44,9)$ & $12(10,5)$ \\
\hline Prófað kannabis & $149(5,2)$ & $22(14,0)$ & $21(22,8)$ & $26(54,2)$ & $17(14,9)$ \\
\hline Höfuðverkur nær daglega & $132(4,6)$ & $17(10,7)$ & $17(18,1)$ & $20(42,6)$ & $17(15,0)$ \\
\hline Magaverkur nær daglega & $101(3,5)$ & $11(6,9)$ & $9(9,6)$ & $12(25,0)$ & $11(9,8)$ \\
\hline Bakverkur nær daglega & $263(9,2)$ & $25(15,6)$ & $17(18,1)$ & $16(33,3)$ & $19(16,8)$ \\
\hline Depurð nær daglega & $208(7,3)$ & $32(20,3)$ & $26(27,7)$ & $16(32,7)$ & $24(21,4)$ \\
\hline Pirringur eða vont skap nær daglega & $239(8,4)$ & $28(17,5)$ & $25(26,6)$ & $18(37,5)$ & $23(20,5)$ \\
\hline Taugaóstyrk/ur nær daglega & $218(7,6)$ & $32(20,1)$ & $23(24,5)$ & $16(34,8)$ & $21(19,1)$ \\
\hline Svefnörðugleikar nær allar nætur & $262(9,2)$ & $27(16,9)$ & $25(26,9)$ & $19(40,4)$ & $32(28,6)$ \\
\hline Leggur í einelti oft í viku & $13(0,5)$ & $4(2,5)$ & $3(3,2)$ & $12(24,5)$ & $8(7,1)$ \\
\hline Lögð/lagður í einelti oft í viku & $5(0,2)$ & $0(0,0)$ & $1(1,1)$ & $10(20,8)$ & $5(4,5)$ \\
\hline Líður alls ekki vel í skóla & $262(9,2)$ & $27(16,9)$ & $25(26,9)$ & $19(40,4)$ & $32(28,6)$ \\
\hline \multirow[t]{2}{*}{ Ild } & \multicolumn{5}{|c|}{ Hefur einhverjum tekist að hafa við pig samfarir eða munnmök gegn pínum vilja? } \\
\hline & Aldrei & Einu sinni & Nokkrum sinnum & Oft & Neitar að svara \\
\hline Reykir daglega & $41(1,4)$ & $8(9,2)$ & $5(11,9)$ & $17(40,5)$ & $17(14,7)$ \\
\hline Orðið drukkin/n oftar en 10 sinnum & $31(1,0 \%)$ & $8(9,0)$ & $6(14,3)$ & $21(50,0)$ & $12(10,4)$ \\
\hline Prófað kannabis & $159(5,4)$ & $21(23,9)$ & $15(35,7)$ & $22(53,7)$ & $18(15,7)$ \\
\hline Höfuðverkur nær daglega & $147(4,9)$ & $12(13,5)$ & $5(11,4)$ & $20(50,0)$ & $17(15,2)$ \\
\hline Magaverkur nær daglega & $108(3,6)$ & $8(9,1)$ & $2(4,5)$ & $11(26,8)$ & $13(11,7)$ \\
\hline Bakverkur nær daglega & $283(9,5)$ & $16(18,0)$ & $5(11,4)$ & $14(34,1)$ & $20(18,0)$ \\
\hline Depurð nær daglega & $237(8,0)$ & $21(24,1)$ & $8(18,2)$ & $14(34,1)$ & $24(21,3)$ \\
\hline Pirringur eða vont skap nær daglega & $258(8,6)$ & $24(27,0)$ & $9(20,5)$ & $17(41,5)$ & $23(20,7)$ \\
\hline Taugaóstyrk/ur nær daglega & $236(7,9)$ & $22(25,0)$ & $10(22,7)$ & $15(38,5)$ & $24(21,6)$ \\
\hline Svefnörðugleikar nær allar nætur & $288(9,6)$ & $18(20,5)$ & $8(18,2)$ & $16(40,0)$ & $33(29,5)$ \\
\hline Leggur í einelti oft í viku & $14(0,5)$ & $4(4,5)$ & $3(7,1)$ & $11(26,2)$ & $7(6,2)$ \\
\hline Lögð/lagður í einelti oft í viku & $4(0,1)$ & $1(1,1)$ & $1(2,4)$ & $10(24,4)$ & $4(3,5)$ \\
\hline Lídur alls ekki vel í skóla & $65(2,2)$ & $8(9,0)$ & $5(11,4)$ & $11(26,2)$ & $11(9,7)$ \\
\hline
\end{tabular}


Rannsóknir hafa sýnt að polendur tiltekins forms ofbeldis eru líklegri til að verða einnig fyrir annars konar ofbeldi. Pannig eru til að mynda polendur eineltis líklegri til pess að hafa orðið fyrir kynferðislegu ofbeldi í æsku. Pá hafa nokkrar rannsóknir sýnt að pessir einstaklingar séu einnig líklegri til að vera gerendur eineltismálum. Pessir einstaklingar eru oft mjög pirraðir og eiga í erfiðleikum með að tjá innbyrgða reiði sem stundum kemur fram í einelti. ${ }^{30}$

Pau tengsl sem koma fram í pessari rannsókn á milli kynferðislegs ofbeldis og áreitni og sálvefrænna einkenna eins og verkja og svefnörðugleika ríma vel við niðurstöður annarra rannsókna. Slík einkenni hafa gjarnan verið tengd aukinni streitu og pví að börn og unglingar hafa oft ekki nægilegan proska til pess að koma vanlíðan sinni í orð. Pá eykur pað enn á streituna að pau eru yfirleitt pvinguð til pess að pegja yfir ofbeldinu..$^{30}$

Раð er athyglisvert hversu slæm staða peirra unglinga er sem neituðu að svara spurningunum um kynferðislega áreitni og ofbeldi. Ekki er unnt að fullyrða með vissu hverjar séu undirliggj- andi orsakir pess að pátttakendur völdu pennan svarmöguleika en hugsanlega tengist pað með einhverjum hætti reynslu af ofbeldi eða áreitni. Рað kann pví að vera að algengið sé vanmetið í pessari rannsókn.

Í ljósi pess hversu alvarlegar afleiðingar kynferðislegt ofbeldi og áreitni gagnvart börnum getur haft á velferð barna og unglinga eru niðurstöðurnar vísbending um að pessi tegund af ofbeldi sé vanmetin sem vandamál í íslensku heilbrigðiskerfi. Í heilbrigðisáætlun til 2010 var til að mynda stefnt að pví að draga úr kynferðisofbeldi um 25\% á næstu árum en öll fagleg umræða um ofbeldi í áætluninni er spyrt við slys og lögð er áhersla á að draga úr áverkum. Í drögum að heilbrigðisáætlun til 2020 er á einum stað minnst á að aðgerðaáætlun um kynbundið ofbeldi sé í vinnslu. Mælikvarðar um ofbeldi fjalla um skráð slys og ofbeldi, ofbeldi í nánum samböndum og heimilisofbeldi en hvergi minnst á mælikvarða um kynferðisofbeldi. Mikilvægt er að heilbrigðisyfirvöld viðurkenni pennan vanda og finni leiðir bæði til að draga úr honum.

\section{Heimildir}

1. Fergusson DM, Horwood LJ, Lynskey MT. Childhood sexual abuse and psychiatric disorder in young adulthood: II. Psychiatric outcomes of childhood sexual abuse. J Am Acad Child Adolesc Psychiatry 1996; 35: 1365-74

2. Pereda N, Guilera G, Forns M, Gómez-Benito J. The international epidemiology of child sexual abuse: a continuation of Finkelhor (1994). Child Abuse Negl 2009; 33: 331-42.

3. Stoltenborgh $\mathrm{M}$, van Ijzendoorn $\mathrm{MH}$, Euser $\mathrm{EM}$, Bakermans-Kranenburg MJ. A global perspective on child sexual abuse: meta-analysis of prevalence around the world. Child Maltreat 2011; 26: 79-101.

4. Dube SR, Anda RF, Whitfield CL, Brown DW, Felitt VJ, Dong M, Giles WH. Long-term consequences of childhood sexual abuse by gender of victim. Am J Prev Med 2005; $28: 430-8$.

5. Hillberg T, Hamilton-Giachritsis C, Dixon L. Review of meta-analyses on the association between child sexual abuse and adult mental health difficulties: a systematic approach. Trauma Violence Abuse 2011; 12: 38-49.

6. Keelan CM, Fremouw WJ. Child versus peer/adult offenders: A critical review of the juvenile sex offender literature. Aggr Violent Behavior 2013; 18: 732-44

7. Skrzypulec V, Kotarski J, Drosdzol A, Radowicki S. Recommendations of the Polish Gynecological Society concerning child sexual abuse. Int J Adolesc Med Health 2010; 22: $177-88$

8. Sigfúsdóttir ID, Ásgeirsdóttir BB, Guðjónsson GH Sigurðsson JF. A model of sexual abuse's effects on suicidal behavior and delinquency: the role of emotions as mediating factors. J Youth Adolesc 2008; 37: 699-712.

9. Bolen RM, Scannapieco M. Prevalence of child sexua abuse: A corrective meta-analysis. Soc Sci Rev 1999; 73: 281-313

10. Priebe G, Svedin CG. Child sexual abuse is largely hidden from the adult society. An epidemiological study of adolescents'disclosures. Child Abuse Negl 2008; 32: 1095-108.
11. Senn TE, Carey MP, Vanable PA. Childhood and adolescent sexual abuse and subsequent sexual risk behavior: Evidence from controlled studies, methodological critique, and suggestions for research. Clin Psychol Rev 2007; 28: 711-35.

12. Mohler-Kuo M, Landolt MA, Maier $T$, Meidert $U$, Schönbucher V, Schnyder U. Child sexual abuse revisited: a population-based cross-sectional study among swiss adolescents. J Adolesc Health 2014; 54 3: 304-11.

13. Brabant ME, Hébert M, Chagnon F. Predicting suicidal ideations in sexually abused female adolescents: 12-month prospective study. J Child Sex Abuse 2014; 23 : 387-97.

14. Sarchiapone M, Jaussent I, Roy A, Carli V, Guillaume S, Jollant $\mathrm{F}$, et al. Childhood trauma as a correlative factor of suicidal behavior-via aggression traits. Similar results in an Italian and in a French sample. Eur Psychiatr 2009; 24 57-62.

15. Kilpatrick DG, Acierno R, Saunders B, Resnick HS, Best CL, Schnurr PP. Risk factors for adolescent substance abuse and dependence - data from a national sample. J Consult Clin Psychol 2000; 68: 19-30.

16. Spataro J, Mullen PE, Burgess PM, Wells DL, Moss SA Impact of child sexual abuse on mental health prospective study in males and females. Brit J Psychiatr 2004; 184: 416-21.

17. Paolucci EO, Genuis ML, Violato C. A meta-analysis of the published research on the effects of child sexual abuse. J Psychol 2001; 135: 17-36.

18. Cheasty M, Clare AW, Collins C. Relation between sexual abuse in childhood and adult depression: case-control study. BMJ 1998; 316: 198-201.

19. Lindert J, von Ehrenstein OS, Grashow G, Gal G, Braehler E, Weisskopf MG. Sexual and physical abuse in childhood is associated with depression and anxiety ove the life course: systematic review and meta-analysis. Int J Publ Health 2014; 59: 359-72.

20. Meewisse ML, Reitsma JB, De Vries GJ, Gersons BPR, Olff M. Cortisol and post-traumatic stress disorder in adults - systematic review and meta-analysis. Brit J Psychiatr 2007; 191, 387-92
21. Tolin DF, Foa EB. Sex differences in trauma and posttraumatic stress disorder: A quantitative review of 25 years of research. Psychol Bull 2006; 132: 959-92.

22. Inchley J, Currie D, Young T, Samdal O, Torsheim T, Augustson L, et al. Growing up unequal: gender and socioeconomic differences in young people's health and well-being. Health Behaviour in School-aged Children (HBSC) study: international report from the 2013/2014 survey, WHO Regional Office for Europe, (Health Policy for Children and Adolescents, No. 7), Kaupmannahöfn 2016.

23. Finkelhor D, Ormrod RK, Turner HA. Lifetime assessment of poly-victimization in a national sample of children and youth. Child Abuse Negl 2009; 33: 403-11.

24. Haugland S, Wold B. Subjective health complaints in adolescence - reliability and validity of survey methods. J Adolesc 2001; 24: 611-24.

25. Olweus D. The revised Olweus Bully/Victim Questionnaire. Mimeo. HEMIL, Háskólanum í Bergen, 1996.

26. Gault-Sherman M, Silver E, Sigfúsdóttir ID. Gender and the associated impairments of childhood sexual abuse: A national study of Icelandic youth. Soc Sci Med 2009; 69: 1515-22.

27. Finkelhor D, Shattuch A, Turner HA, Hamby SL. The lifetime prevalence of child sexual abuse and sexual assault assessed in late adolescence. J Adolesc Health 2014; 55: 329-33.

28. Senn TE, Carey MP, Vanable PA. Childhood and adolescent sexual abuse and subsequent sexual risk behavior: evidence from controlled studies, methodological critique, and suggestions for research. Clin Psychol Rev 2008; 28: $711-35$.

29. Kristman-Valente AN, Brown EC, Herrenkohl TI. Child physical and sexual abuse and cigarette smoking in adolescence and adulthood. J Adolesc Health 2013. 53: 533-8.

30. Mansbach-Kleinfeld I, Ifrah A, Apter A, Farbstein I. Child sexual abuse as reported by Israeli adolescents: Social and health related correlates, Child Abuse Negl 2015; 40: 68-80. 


\section{ENGLISH SUMMARY}

\section{The prevalence of sexual abuse and sexual assault against icelandic adolescents}

Ársæll Már Arnarsson', Kristín Heba Gísladóttir', Stefán Hrafn Jónsson²

Introduction: Sexual abuse and sexual assaults against children and adolescents is one of the most significant threats to their health. The aim of the current study was to investigate its prevalence and effects on Icelandic teenagers in the $10^{\text {th }}$ grade.

Material and methods: The study is based on data collected for the Icelandic part of the HBSC-project (Health and behaviour of schoolaged children). Standardized questionnaires were sent to all students in $10^{\text {th }}$ grade in Iceland of which 3,618 participated. The students experience of sexual abuse or assaults was assessed by asking them how often they had been against their will a) touched in a sexual way, b) made to touch someone else in a sexual way, c) the subject of an attempted rape or d) subjected to rape.
Results: The results showed that $14.6 \%$ (527) participants had experienced sexual abuse or assault. Of these, $4.5 \%$ (162) had one such experience but $10.1 \%$ had either suffered certain type of abuse or assault more than once, or had experienced more than one kind. About $1 \%$ of participants (35) said that they had suffered many times from many forms of abuse and assaults. The prevalence of poor mental well-being and risk behaviour was much higher amongst those that had experienced sexual abuse or assault.

Conclusion: Although the results show that the prevalence of sexual abuse and assault against Icelandic adolescents is similar to other Western countries, we find it to be higher than a previous study a decade ago.

${ }^{1}$ School of Social Sciences and Humanities, University of Akureyri, ${ }^{2}$ School of Social Sciences, University of Iceland.

Key words: Sexual abuse, sexual assault, adolescents.

Correspondence: Ársæll Már Arnarsson, aarnarsson@unak.is 